\title{
Fabrication of Immunosensor Based on Au-silica Nanocomposite for Neuron-specific Enolase Detection
}

\author{
Bin Wang ${ }^{\#}$, Tao Liang ${ }^{\#}$, Jie Li, Hua Yu and Xiangyang Chu* \\ Department of Thoracic Surgery, PLA General Hospital, No.28 Fuxing Road, Beijing, 100853, P.R. \\ China \\ \# These authors contribute equally \\ *E-mail: xiangyang_chu168@foxmail.com
}

doi: $10.20964 / 2017.08 .05$

Received: 7 April 2017 / Accepted: 28 May 2017 / Published: 12 July 2017

\begin{abstract}
Neuron-specific enolase (NSE), a type of neuroendocrine molecule, is a putative serum marker for small-cell lung carcinoma. This work addressed the fabrication of a signal-enhanced, label-free, electrochemical immunosensor based on Au nanoparticle/mesoporous silica nanoparticles (Au-MSNs) for NSE determination. Because of the large number of active sites provided by the $\mathrm{Au}-\mathrm{SiO}_{2}$ sensor, the modified immunosensor has a significantly enhanced sensitivity. Furthermore, during quantitative NSE detection, the sensor has a desirable linear relationship with the concentration $(0.1-2000 \mathrm{ng} / \mathrm{mL})$ and a detection limit of $0.05 \mathrm{ng} / \mathrm{mL}$.
\end{abstract}

Keywords: Label-free immunosensor; Neuron-specific enolase (NSE); Signal-enhanced; Electrochemical immunosensors; Silica

\section{FULL TEXT}

(C) 2017 The Authors. Published by ESG (www.electrochemsci.org). This article is an open access article distributed under the terms and conditions of the Creative Commons Attribution license (http://creativecommons.org/licenses/by/4.0/). 